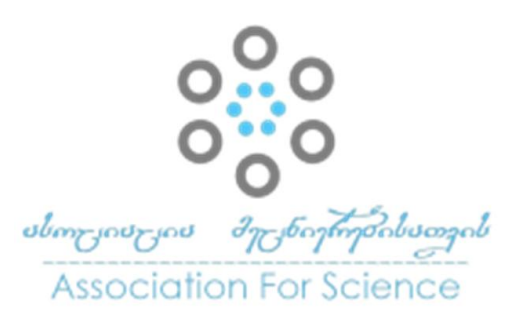

Georgian Scientists

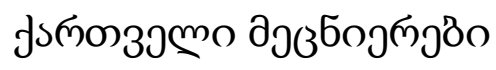

Vol. 3 I ssue 3, 2021

https://doi.org/10.52340/gs.2021.08.03

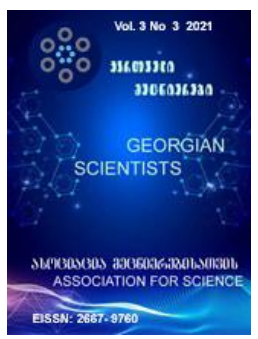

\title{
2018 Presidential elections in Georgia
}

\section{(Elections without a leader)}

\author{
Avtandil Tukvadze ${ }^{1}$, Akaki Abzianidze², I rakli Ubilava³, Helen Gelashvili ${ }^{4}$ \\ ${ }^{1}$ Ivane Javakhishvili Tbilisi State University, Associated Professor \\ ${ }^{2}$ National University of Georgia SEU, Professor \\ ${ }^{3}$ PhD student, Department of policy analysis and management Russian University of friendship of peoples (M oscow, \\ Russia).
}

4PhD student of Political Science, Assistant of Professor of the Faculty of Social and Political Sciences, Ivane Javakhishvili Tbilisi State University

\section{Annotation}

The article notes that the Constitution of 2018, which came into force since the inauguration of the President, establishes the model of Parliamentary governance in the country and this was the last time President was chosen through universal public elections (6 year term), from 2024 President will be chosen (for 5 years) by election board and Country will totally shift to Parliamentary form of governance. The work analyzes aggressive pre-election campaign factors: socio-economic conditions, the management team's mistakes, features of political culture, contrast of Georgian mentality and consciousness, mutual accusations of candidates in protecting Russia's interests - the "war with compromises", pre-election promises of Salome Zurabishvili and Grigol Vashadze, Government resources used in favor of a government-supported candidate, preliminary reports published by international (according to which the legitimacy of the election was not doubted, but there were critisizing comments), new initiatives announced in inauguration speech of newly elected President (democratic values and political priorities), which gives the public hope for the future.

Keywords: President, elections, leaders, aggressive rhetoric, Russia, political culture, compromises. 


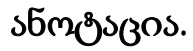

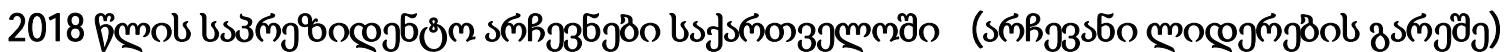

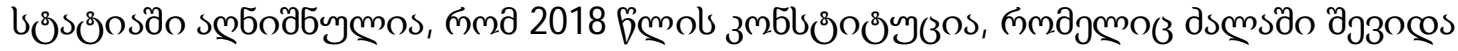

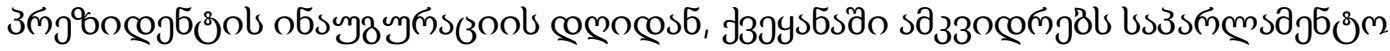

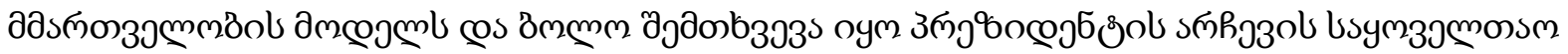

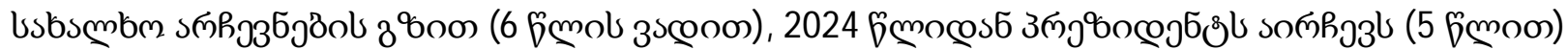

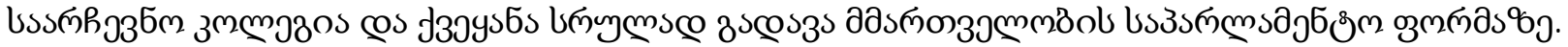

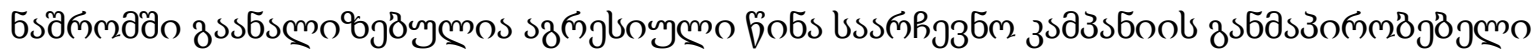

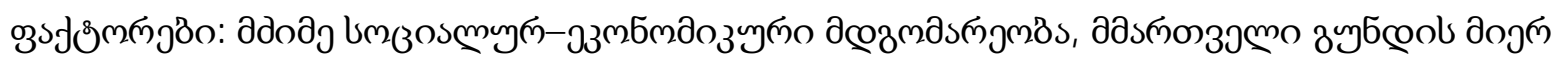

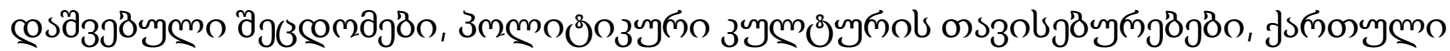

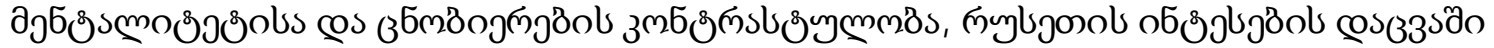

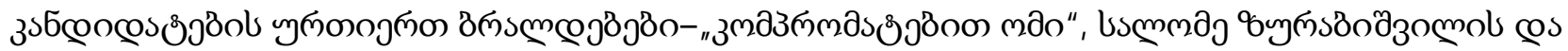

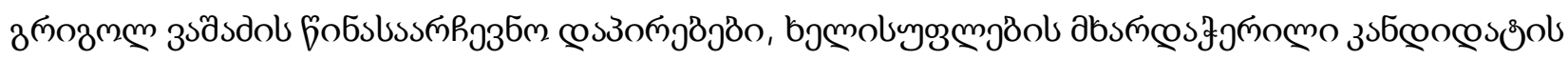

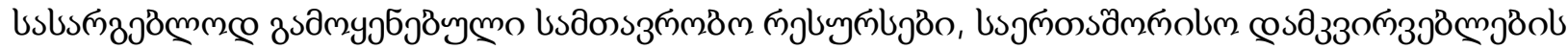

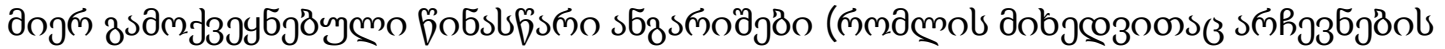

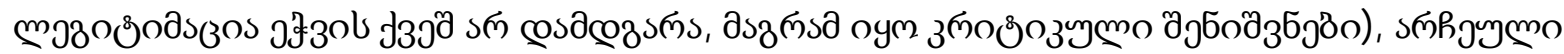

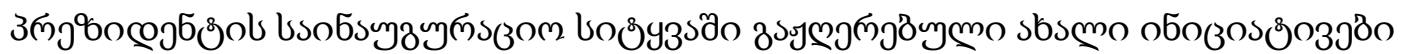

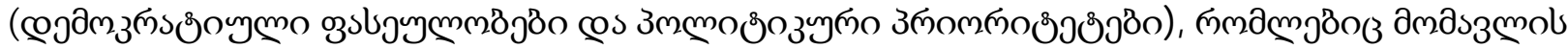

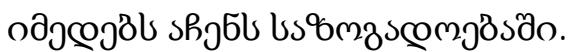

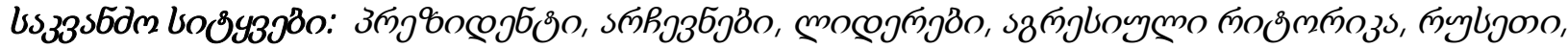

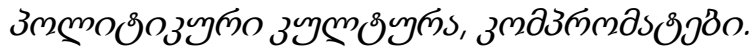




\section{Introduction.}

33 changes have been made to the current constitution of the transitional period, country moved from American model of Presidential Governance (1995) ${ }^{1}$ to semi-Presidential French model (2004), and later through the Polish M odel of the Parliamentary Republic (2004), ${ }^{2}$ The Constitution of 2018 establishes the classical government of the Parliamentary Governance. This is a general characteristic of the constitution that has been adopted since the 1990s, since after their study we are convinced that they have very few connections with "A merican" and "French" analogs and the main purpose is not to seek the form of governance that is acceptable to the Georgian State, but adoption of a constitution that is tailored to the interests of a particular political force. Numerous constitutional amendments aimed to increase the executive power, in particular increasing the rights of the President. However, none of the Presidents have been elected for more than two terms in Georgia, we can not say the same about the majority of post-Soviet States. Constitutional status and real power of Presidents have never been in compliance with each other during the transitional period in Georgia, especially during the Presidency of Mikheil Saakashvili, the margin between the party and the State was absent and the State functioned as repressive machine, while the democracy was left in the field of rhetorics and theory and in real life there was no guarantee of protection of constitutional human rights. It is important to note that the model of the US Presidential Governance has brought democracy only to the A merican people, and its transplantation, like in Georgia, has established super Presidential authoritarian regimes in most countries of A frica, A sia and Latin America. The reason is that the US constitution is the result of the development of American political culture and political history, expressing the political aspirations of the American people and their mentality.

The Constitution of 2018, which came into force since the inauguration of the President, is a model of Parliamentary rule in the country and has been the last occasion of el ecting the President (6 years) through the general elections, whose powers are significantly reduced and is similar to the status of the head of State of the Parliamentary Republic. The experiences of previous years show that the President's high legitimacy has created problems (like Poland) between the perception of power and the real power of the branches of the government.

The next President will be elected by Election Board ( 300 members) for a term of five years and the same person who has lived in the country for 15 years and has reached 40 years of age can only be elected twice. In fact, the country's constitutional model of strong, undefined Presidential rights is gradually moving to the weak Presidential institution according to the Parliamentary form of governance.

\section{Constitutional status of the President of Georgia.}

${ }^{1}$ Constitution of Georgia. Tb; 1995

${ }^{2}$ Constitution of Georgia. Tb; 2004 
According to the Constitution, the fifth President of Georgia will be the head of State, guarantee of national unity and national independence, Supreme Commander and presenter of the country to the international arena.

The future President is a symbolic, representative figure. ${ }^{3}$

The President of Georgia will conduct internal and foreign policy with the consent of the Prime M inister, the Security Council existing with the President will be abolished completely. "The President will be the Chairman of the National Defense Council, which will be created during the war." 4 The President shall retain the right of veto, according to the request of the Parliament Speaker and Parliament M embers (not less than $1 / 4$ ) or by the request of the Government to appoint an extraordinary session, in case of the President's declaration of war or State of emergency, Parliament is obliged to convene an extraordinary session.

If the legislative body fails to approve its new composition within two weeks after the resignation of the government, the President should dissolve the Parliament and appoint early elections.

The President will have the right to appoint three of the nine members of the Constitutional Court and one of 14 members of the High Council of Justice to appoint and participate in the appointment of the Chairman and Members of the Central Election Commission.

Besides, she will be able to appoint or dismiss the President of the National Bank.

Also, the President of Georgia is entitled to appoint a referendum on the issues constituted by the Constitution and the law at the request of Parliament, Government or at least 200,000 voters within 30 days upon receipt of such request.

The resignation of the President is only possible through impeachment.

The initiation of impeachment procedure will be possible by the Parliament of Georgia with no less than $1 / 3$ consent.

According to the following procedures, the case must be handed over to the Constitutional Court, which will have one month to prepare the case and the conclusion. In case of Parliamentary consent, the issue should be considered and voted under two weeks times. The consent of the 2/3 of deputies is necessary for the impeachment of the President.

However, there is a limit. In case of war or emergency situation in the country, the initiation of the President's impeachment is prohibited.

If the President gives up his powers prematurely, the Chairman of the Parliament will fulfill his duties.

${ }^{3}$ Constitution of Georgia. Tb; 2018 P. 25

${ }^{4}$ Constitution of Georgia. Tb; 2018 P. 42 
The Head of State will be able to unilaterally make decisions such as granting citizenship, pardoning convicts, State prizes and awards, higher military, special and honorary rankings, as well as higher diplomatic rankings.

The President will be able to sign the Constitutional A greement with the Georgian Orthodox Church on behalf of the State.

The President of Georgia is authorized to appeal to the people. Once a year, she will submit a report to the Parliament on the most important issues about the State of the country. ${ }^{5}$

Pre-election environment was influenced by: A. The hard socio-economic situation - impairment of the GEL has almost deducted the cash revenues of the employeed population (1 US dollars in 2013 was $1.73 \mathrm{GEL}$, and in 2018 the value of 1 USD was varied within $2.66-2$ to 70$)^{6}$. Part of the population who had debt in dollars were particularly affected; Pension is equal to 70 dollars. The number of unemployed has increased significantly; outflow of the country's w ork capable population abroad has increased (since 1989 the population has decreased from 5 401,000, to -3720.4 by 2016); prices for energy and food was increased. The process of economic impoverishment of citizens was supported by numerous overdue loans. All of them greatly promoted polarization of political orientation of citizens.

B. M istakes made by the ruling team that may be linked with the extra self-confidence during the pre-election period and government initiative to cultivate and export cannabis. Opposition leader Vashadze used the advice of his political scientist (Viktor Shkliarov, a US citizen), used the cannabis topic and began to collect signatures, thus attracting supporters who opposed the cultivation and export of cannabis. The Patriarchate also expressed a negative reaction about the cannabis topic. Part of the church was politically motivated to support Grigol V ashadze. The Patriarch's appeal that the church authorities should not interfere with the election campaign, partly suspended the propaganda activities of the clergy against Zurabishvili, but the negative charge could not be reduced. The government showed a delayed reaction and revoked Cannabis Cultivation initiative.

C. The Presidential election was distinguished with extreme aggression and the reason for this is to be looked in the rules of the "political game" established in political culture: the inclination towards violence and violence in political culture is primarily related to the communist heritage that has been associated with dissociative subculture from the Soviet era like the omniscient ideology, the Gamsakhurdia government was characterized by uncompromisiness and denial of heritage, and in the absence of political institutions, their leaders embarked on extremist and radical ideology in public consciousness 7; Radical ism and confrontation are largely linked to M ikheil Saakashvili's authoritarianism - a model of the "party-government", when the National party actually "privatized the State " in their favor. M ikheil Saakashvili, by forming an actually repressive State, established

${ }^{5}$ Constitution of Georgia. Tb; 2018 P. 29

${ }^{6} \mathrm{https}: / /$ www.google. com/search?q=GEL impairment dynamics since 2014

${ }^{7}$ A.Tukvadze. Transformation of the political system in modern Georgia, in the journal: Central Asia and the Caucasus 2006 2(44) Sweden, Sweden 103-112. 
violence in political life as a norm. Saakashvili rejected legacy in politics, established hostility between generations and different social groups, split public consciousness, imitating W estern values instead of national values, established an authoritarian State based on cosmopolitan outlook. ${ }^{8}$ $M$ embers of the $N$ ational M ovement had legalized limitless privileges, and uncontrolled influence in the country. Today they are distinguished with very aggressive and uncompromising actions. The reason for this is the loss of privileges, judicial decisions against their representatives and permanent demands for restoration of justice from society.

D. Any election campaign is affected by peculiarities of people's mentality, psychological mood and emotional components, which have been formed over the centuries and find expression in everyday life. Despite the fact that Georgians have rich traditions of religious and ethnic tolerance and there are many examples to prove this, they cannot boast with experience of political pluralism and plethora of political parties is not enough: the transition period does not know the concept of constructive opposition. One of the reasons for this is found in Georgian character- excessive emotional attachment to leaders derives from the specifics of Georgian mentality and public consciousn ess: the famous Georgian historian, geographer and cartographer of the 18th century Vakhushti Batonishvili believes that the Georgians equally had ability of "being hostile and friendly, supporting during bad times and good times" and they are similarly successful in "choosing the good over the evil." The main feature of Georgian nature is contrastability. Our character is difficult and contradictory. W e know plague and feast both in excessive forms, as well as love and hate, morality is miraculous high and staggeringly low immorality.

The contradictory qualities of the Georgian people coexist in extreme forms - the ultimate idealism is combined with extreme realism: the excessive emotional attachment of citizens to President Zviad Gamsakhurdia has strengthened the el ements of M essianism in political culture, and on the other hand, confrontation with him caused inclination towards hatred and violence: relatives of people who died on the opposite sides during the civil war of the 90 s, did not share mourning with each other. This happens in the people whose folk ballad ("Tiger and the knight") describes the un precedented event of martyrdom in the history of the world - the mother of the man who died in the battle goes to a mother of a tiger who also dies in that battle to say her condolences ("maybe his mother is mourning just like me"); i.e. this woman has shown a great ability of sharing similar plague and humanism, identified pain of the deceased animal's mother with her own and her son's love. ${ }^{9} 8$. P. 1

Candidates' pre-election promises, according to the Electoral Code, "can not contain the urge to incite hatred, call for overthrow of State sovereignty and such difficult issues." In other cases, the election legislation "does not regulate the content of the Presidential candidates' pre-election promises". ${ }^{10}$

\footnotetext{
${ }^{8}$ A.Tukvadze. Comparative analysis of political culture. Tb; 2014 P. 125.

${ }^{9}$ A.Tukvadze. Transformation of the political system in modern Georgia, in the journal: Central Asia and the Caucasus 2006 2(44) Sweden, Sweden 103-112.

${ }^{10}$ A.Tukvadze. Comparative analysis of political culture. Tb; 2014 P. 125.
} 
25 candidates have participated in the first round of elections, their promises have gone beyond the Presidential powers: "Power is in unity - we can change it together!" This is the el ection slogan of the Presidential candidate of the United Opposition. According to the leaders of the National M ovement, their main message and promise is that Grigol V ashadze will end the Bidzina I vanishvili's "Government ". Grigol V ashadze's pre-election promises included pardoning "political prisoners" Saakashvili, M erabishvili, A khalaia, Tsaadze. In the first round such intentions attracted the maximum participation of the National movement supporting electorate, but in the enforcement part and in the second round it was the announcement of destabilization and the voter's turnout was taken in favor of Zurabishvili. According to Vashadze, he will lead a hundred thousand supporters in the street and force the government to appoint early Parliamentary elections. E. i. Elections have become the outcry that government should go, and the winner can didate gets the mandate to change the ruling force. This is why we got a high level of confrontation in the second round. After the defeat of the opposition by $20 \%$, the opposition intentionally tried to disrupt the President's inauguration, these plans were disrupted by the effective actions of the government and they failed to change the government with "Saakashvili's scenario", Vashadze announced permanent actions, saying that the he would overthrow the government with constitutional means, but the protests stopped due to the lack of supporters.

Grigol Vashadze's false promises to increase the pensions up to $400 \mathrm{GEL}$ worked due to tw o reasons: first, populism played a leading role in Georgian politics and reached its zenith during Saakashvili's Presidency, when the timeframe for becoming NATO and EU member was reduced and the existing authoritarian regime in the country was sold as democracy ("political schizophrenia" this is what Steven F. Jones calls the promises of National movement ${ }^{11}$ ); Secondly, pensioners are the most vulnerable group of society, pensions are not enough to meet the minimum requirements and naturally their support has increased the number of $V$ ashadze's electorate.

Salome Zurabishvili's, an independent Presidency candidate supported by the Georgian Dream, main slogan is "Together for Georgia". The main message of her election campaign is to look forward to the future, to understand the role of the President as a above party figure, the arbitrator in political processes, the focus of the country's historical past, the first w oman President, protecting the interests of all citizens, and about the functions of the President. However, her Statement was unclear for the people: "The President should be with the people, but still higher." The wave of Black PR, her Statements about the war of 2008, confidence of the government, European-style el ection campaign, lack of populistic promises and lack of knowledge of the Georgian language significantly reduced her rating, The Georgian Dream's candidate is running the first round of the el ection campaign with excuses, so it is difficult to evaluate her election campaign positively.

\footnotetext{
${ }^{11}$ A.Tukvadze, U. Bluashvili. Peculiarities of Georgian character. See International reviewed and referential Scientific Journal. "Science and Life". Tb; 2011 №1(3) P. 101-102.
} 
$46.74 \%$ of the $3,558,437$ voters participated in the first round. Georgian D ream's candidate Salome Zurabishvili received 615,572 votes, which constituted 38,64\%, and the United Opposition (11 party) "Power is unity" "Presidential candidate Grigol V ashadze received 601,224 votes, 37.74 percent. ${ }^{12}$

According to the results of GA LLUP INTERNATIONAL order by TV Company "Imedi", Salome Zurabishvili has $58 \%$ and Grigol V ashadze has $42 \%$ in the first round, which was unrealistic. ${ }^{13}$

The political biographies of the candidates (Zurabishvili, Vashadze) who moved to the second round are different, but both of them at various times were appointed as foreign minister by Saakashvili.

Sal ome Zurabishvili was born in Paris in 1952 in the family of Georgian political emigrants and she is grandaughter of the famous public figure Niko Nikoladze.

In 1972 she graduated from the Paris Institute of Political Sciences, Columbia University in 1973, and in 1981 the National School of Management of Paris. She was the professor of the Institute of Political Sciences of France in 2006-2015.

The French stage of Zurabishvili's diplomatic career, which started in 1974 and continued until 2003 is pretty diverse. He worked at various positions at the M inistry of Foreign Affairs, UN, OSCE, NATO headquarters, in W ashington, Rome, in the Republic of Chile, as A mbassador to Georgia.

In February 2004, Georgian President Mikheil Saakashvili appointed Salome Zurabishvili as M inister of Foreign Affairs of Georgia. ${ }^{14}$

The greatest achievement of his post on the position of M inister of Foreign Affairs was signing a document on withdrawal of Russian military bases from Georgia on M ay 19 of $2005^{15}$

Sal ome Zurabishvili has created "a new group of Friends of Georgia", Ukraine, Lithuania, Latvia, Estonia, Romania, Bulgaria, the Czech Republic and Poland, which are supporting Georgia in the NATO and EU membership.

In few months after a successful agreement with Russia, Salome Zurabishvili was dismissed from the minister post. Reason: "lack of professionalism, nepotism and lack of results in foreign policy". Since October 2005, she moved to the opposition and established the party "Georgia's W ay", which was based on the right-wing ideology. ${ }^{16}$ In the conditions of Saakashvili's authoritarian regime her party failed to succeed in the elections and Salome Zurabishvili left Georgian politics in 2010 and said: "In this country the democracy is no longer and the opposition cannot be any longer. Being in opposition

\footnotetext{
12 netgazeti.ge/ news/314260/ Netgazeti | Unfulfilled promises of candidates (seen on 27.11.2018)

${ }_{13}^{12}$ 12.S. F. Johns. Democracy in Georgia https://.www.cicerofo undation.org.legtures.StephenJonesGeorgia. pdf (seen on March 3 of 2017)

${ }^{14}$ The results of the first round of the elections were summarized | imedinewshttps://imedinews.ge >

${ }^{15}$ The exit poll results assessed by the ruling team/ imedinews https://imedinews.ge >

${ }^{16}$ Salome Zurabishvili appointed as the Foreign Minister of Georgia on Saturday. www.radiotavisupleba.ge. (Read on Novemebr 30 of 2018.)
} 
in such conditions means that we are taking part in illusions and lies of the government. I can not take part in this lie." 17

Since 2012, when government in Georgia has changed, Salome Zurabishvili returned to the politics in 2013, she offered her candidacy for the Presidential el ections, but she was citizen of Georgia and France at the same time, so the Central Election Commission rejected her Presidential candidaacy. ${ }^{18}$ from 2016 to December 12 of 2018 she was a member of a Parliament until was elected as a President. 19

On September 9 of 2018, the party "Georgian Dream" supported indepen dent candidate, Salome Zurabishvili, as the Presidential candidate. ${ }^{20}$

Since August 23 of 2018, the Presidential candidate Salome Zurabishvili gave up French citizenship. ${ }^{21}$

Grigol Vashadze (born in 1958 in Tbilisi) - Georgian diplomat and politician; Has been granted the diplomatic rank of the plenipotentiary and extraordinary envoy.

In 1981 he graduated from M oscow State Institute of International Relations, Faculty of International Law. In 1981-1988 he worked at the Department of International O rganizations at the M inistry of Foreign A ffairs of the Soviet Union and later in the Space and Nuclear W eapons Division. In 19881990 he was a graduate of the Diplomatic Academy.

From 1990 to 2008, V ashadze was busy with private business and managed companies founded by him: "Georgia Arts M anagement" and "Gregory Vashadze and BR".

In 2004, with the invitation of M ikheil Saakashvili, Nino Ananiashvili arrived in Georgia with her husband (Grigol Vashadze) and became the art director of the ballet troupe.

Grigol V ashadze on February 2 of 2008, was appointed by Saakashvili as Georgia's Deputy M inister of Foreign Affairs, Minister of Culture, M onument Protection and Sports of Georgia on November 2, and from December 6 of 2008 to 2012 was a Minister of Foreign Affairs ${ }^{22}$

The main achievement of Grigol Vashadze was the so-called "non recognition" policy after the A ugust 2008 war, which aimed to hinder the recognition of independence of Abkhazia and South Ossetia at international level.

He speaks Russian, English, Portuguese, I talian, Spanish and French languages. ${ }^{23}$

${ }^{17}$ Salome Zurabishvili's path to the Presidency. www.ghn.ge. Read on: December 4 of 2018.

${ }^{18}$ Salome Zurabishvili opened the first office of her public movement. civil.ge. Read on: December 4 of 2018

${ }^{19}$ Salome Zurabishvili's political timeout www.radiotavisupleba.ge. (read on: December 2 of 2018).

${ }^{20}$ Salome Zurabishvili about the Presidential elections. www.radiotavisupleba.ge. (Read on: December 11 of 2018).

${ }^{21}$ Parliamentary elections 2016 - second round. cec.gov.ge. (read on: November 30 of 2018.)

${ }^{22}$ Georgian Dream will support Salome Zurabishvili during the Presidential elections. on.ge. (Read on: November 18 of 2018.)

${ }^{23} 21$.Salome Zurabishvili refused the French citizenship. netgazeti.ge. Read on: November 16 of 2018. 
"W ar with compromises". Presidential candidates failed to involve citizens into discussions about the long-term strategy of the State and their election campaign was built on mutual demonization and unconstructive opositioning. The leaders of the National Movement were not avoiding dirty methods and in the majority of cases they lied using mass media; National movement TV "Rustavi 2" successfully utilized the successful method of releasing numerous records that were related to Bidzina Ivanishvili and other State official's corrupt business deal with Zaza Okuashvili founder of "Omega" and TV 1.

To discredit Salome Zurabishvili and radicalize the situation the opposition TV channel violated every norm of the journalism ethics, began from ranking Zurabishvili supporters as "secondary citizens" continued with releasing recordings on TV and manipulating with bereaved fathers' interests, this launched quite crow ded protest, where the leaders of the National Movement were drawn as "defenders of truth". In the second round TV company "Imedi" was actively involved in the campaign "without rules" against V ashadze.

There w ere compromises about private life, as well as fragments from their past, and many other, but central positions, and the defining influence was if which candidate defended Russia's interests and betrayed the country; After the war in 2008, the perception of Russia as the enemy was not very difficult.

"The Russian factor" took the central place in the war with compromises. All the opposition forces emphasized the remarks made by Salome Zurabishvili at different times, citing his writings: "That night Saakashvili opened fire on Georgians, his compatriots, opened fire and launched rockets ... led to an expected Russian military reaction, achieved expected defeat and" planned" loss of territories. He has not yet been convicted for this crime. "I'm not supporting the establishment of American base in this country, because anyone knows the geopolitical situation, they understand that establishing the US base is more dan gerous than security. This does not mean that we are refusing to partnership." 24

In the first round, the self-confident ruling elite Stated that the Presidential can didate does not need an electoral program and also was in using compromises, as such approach does not correspond to Salome Zurabishvili's European election campaign. In the second round the situation is extremely tense and government supporting TV channel "Imedi" switches to emergency regime and releases lots of compromises on Grigol Vashadze: was accused of working with the KGB, workings at M inistry of Foreign Affairs of the USSR was discredit; $\mathrm{H}$ is political Statements were used against him: "Russian citizenship - in general Russia - is a part of my life, does not have any significance, if I have a Russian passport in my pocket or not." 25 "W e are part of Russian culture and we have two native languages."

${ }^{24}$ Grigol Vashadze's biography, online edition "civil.ge".

${ }^{25}$ M inistry of Foreign Affairs of Georgia - Biography; Read on: 3/18/2011

${ }^{26}$ Nino Kharadze. Salome Zurabishvili vs Grigol Vashadze. Tb; Radio "Freedom" 2018 
"Georgian Dream" focuses on the resolution adopted by the Council of Europe about the 2008 war, which was signed by United National M ovement deputies of the European Parliamentary A ssembly: "However, on August 7, 2008, by bombing Tskhinvali by the Georgian military forces without warning, escal ation moved to new, open and full-scale warfare. Using heavy artillery and cluster bombs, which posed serious danger to the civilian population, was disproportionate use of military force by the Georgian side, despite the fact that this was happening within its territory, and as such action was a violation of international humanitarian law and of the commitments undertaken by the State to decide the conflicts with peaceful means.

6 .... This has led to the occupation of important part of Georgian territory, as well as damages to the economic and strategic infrastructure, which may be considered as either a direct attack on the sovereignty and therefore a violation of the Charter of the Council of Europe, or Russia's attempt to expand its influence on the nearest border country, by violating its obligations, including refusal of such concepts. ${ }^{.27}$

Salome Zurabishvili's Statements did not go byond the scope of the adopted resolution, but the united opposition's propaganda machine managed to beat Salome Zurabishvili with former military highranking officials, life threatening messages were sent towards the Presidential candidate;

The candidate who moved to the second round was supported by previous National party members "European Democrats" and their leader Davit Bakradze (who received 10\% of the vote in the first round), also, the "Republican Party", which was always came to power with "someone else's train," they were followed by other political unions.

The support of "European Democrats" did not mean the mechanical transition of votes in favor of $V$ ashadze, as their electorate did not share the prospect of $\mathrm{N}$ ational M ovement coming to power with the. Three non-governmental organizations Transparency International, Y oung Lawyers A ssociation and Fair Elections blame the authorities for making false IDs without evidence and openly defended the interests of the National M ovement.

The ruling party only woke up in the second round and realized that the danger to their unilateral hegemony in the political space was real (in fact loosing the fight for the weak position of President, made pardoning of Saakashvili Akhalaia and others, made instability and civil war in the country at least realistic) and launched completely different kind of campaign: in the second round, Moshe Clughauft, a polit-technical adviser was invited from Israel, working in favor of Zurabishvili, at this time anti United National M ovement banners appeared, videos and slogan "principle choice" appeared in Tbilisi. W ith the advice of M oshe Clughauft al ong with Salome Zurabishvili, on the banners appeared the faces of Bidzina Ivanishvili and other party leaders, indicating that the Presidential candidate was supported by the ruling party. Salome Zurabishvili started the second

${ }^{27}$ Minister of Foreign Affairs Grigol Vashadze again in concession of Russian citizenship, 2011 
round of the election campaign with a very aggressive message: she will not give up Georgia to Russia and $V$ ashadze and specified that the choice is between Russia and Europe.

The number of voters needed to be increased in the second round because many Georgian Dream supporters did not participate in the first round; The second round of the election campaign was built on the threat of expected destabilization and the possible return of the "National M ovement" government; The banners appeared with pictures of Saakashvili, A khalaia, Kardava and A deishvili, "no to Nazis, not the evil" written on them. In 2012 Parliamentary elections Bidzina Ivanishvili convinced citizens to take part in elections and this decided the fate of the el ections, but the Georgian Dream's government could not justify the expectations of the people and consequently trust in it's leader decreased. I vanishvili realized everything and he returned to the post of party chairman in A pril 2018. The government's promise to increase the pensions ( $180 \mathrm{GEL}$ ) by $20 \mathrm{GEL}$ was not enough (Vashadze's promise of 400 GEL pension was more charming); Ivanishvili criticized the rules of unfair play in the banking sector. A year-old initiative to dismiss the debtors from debt was activated and specified only prior to the second round, that only those debtors would be dismissed from their debts whose loan base did not exceed $2000 \mathrm{GEL}$. After the el ections, approximately 600000 debtors were dismissed from their debts (4 billion GEL) and this obligation was taken by the Cartu Foundation, which was founded by I vanishvili. This fact played an important role in the favor of Presidential candidate. Ivanishvili had previously provided assistance to the citizens when he was performing "State functions" - covering pension debts and paying salaries to Saakashvili's government officials.

According to the CEC data, in the second round 56.23\% participated from 3,558,437 voters, from which the candidate of the Georgian D ream, Salome Zurabishvili received 59.52\% (1147627 votes), and the candidate of the United Opposition Grigol V ashadze received $40.48 \%$ (780633 votes). The CEC data was very close to the results of the exit polls (GALLUP INTERNATIONAL and EDISON Research). ${ }^{28}$

International observers assessed the second round of the Presidential elections as conducted in a competitive en vironment and the candidates were given the opportunity to conduct the pre-election campaign freely, but one of the candidates had an advantage - said in a preliminary report of the Office for Democratic Institutions and Human Rights Office (OSCE / ODIHR) and its partners-eu Ossetian Parliamentary A ssembly (OSCE PA), the European Parliament (EP) and the Parliamentary A ssembly of the Council of Europe (PACE). The election process has been negatively affected with both rigid rhetoric and violent incidents, as well as the use of administrative resources and the involvement of high-ranking officials of the ruling party in the pre-election campaign. An assessment was made that the margin in the second round of elections betw een the party and the State became vague: ${ }^{29}$

\footnotetext{
${ }^{28} \mathrm{https}: / /$ www.youtube.com/watch?v=elXpF_jTbb0 (Seen on December 18 of 2018)

${ }^{29} \mathrm{http}: / /$ portal.coe.ge/downloads/Resolutions/Res1633(2009)Geo.pdf) (Seen on December 15 of 2018)
} 
O bservers outlined government initiative of dismissing the debts of 600,000 citizens. This can be regarded as a bribery; For the second tour, there was a sharp inequality between financial donations, in favor of a candidate supported by the ruling party; The Central Election Commission appointed the second round of the Presidential election in the middle of the week, which did not express the interest of the voters and raised doubts about political motivation; The Public Broadcaster has taken a biased position against the opposition. Private media maintained a polarized position;

National-Democratic Institute of the United States of A merica assessed the elections of 28 November. According to the NDI report, the second round of the Presidential el ection was negative and damaging to democracy: ${ }^{30}$

Overall, "Elections, by both NATO and other international organizations, including the OSCE, have been assessed as open and fair. How ever there was some criticism towards high political rhetoric and we saw it. There was a demand for the creation of a tranquil political environment and we hope that this will happen in future el ections, but the final assessment was positive." 31

Conclusion. The second round of Presidential elections was appointed for the first time in the history of Georgia. Sal ome Zurabishvili's P residential election campaign was based on the methods of European type "political game" and was almost empty of emotional speeches and populist promises (while populism and emotions are a sign of leadership skills in Georgian reality and corresponds to the psycho-emotional State of Georgians) and mostly emphasised the functions of the President as an arbitrator and above party person (in the opinions of Salome's closed persons she is more convincing when speaking in French and English:: Mouche Cloughaft claims that Salome is a leader and thus she hardly accepts advices), but she used the method of accusing the opponent in being pro-Russian. As for Vashadze, he referred to political force united around Ivanishvili as "government" and aimed to change it (respectively, the "dream" was figting to maintain power, as V ashadze announced pardons and early elections, which meant at least civil conflicts and the prospect of changing the government), he was supported by interests of several non-governmental organizations, defenders of National M ovement. Vashadze's supporters were mainly the electorate of M ikheil Saakashvili (V ashadze unsuccessfully played the role of the leader), the absolute majority of which participated in the elections, and the angry voters who were part of the pensioners, but the involvement of the population in the second round increased, the possibility of returning of the $\mathrm{N}$ ational Movement and the threat of destabilization surpassed the negative attitude tow ards the government and increased the number of votes in favor of Salome Zurabishvili. The government initiative of nullifying the debts played a significant role. Because of this fact, the observation missions did not undermine the legitimacy of the elections, but none of them suggested that the 2018 Presidential election was a "step towards democracy".

\footnotetext{
${ }^{30}$ https://droa.ge/?p=38356 (Seen on November 30 of 2018)

${ }^{31}$ International Election Observation M ission Georgia - "Presidential Elections, Second Tour" 28 November 2018.
} 
The elections showed that there is an acute crisis inside the ruling political elite and it does not derive from ideological confrontation, but rather from the business interests of individual groups or even political ambitions. "The short but fervent Presidential campaign has outlined the astuteness and emptiness of the Georgian political elite" 32

Low activity of citizens in the first round of the Presidential election indicates the alienation and distrust towards the political elite. The high trust man date of the population, which "Dream" has received in the 2012 elections, is expiring. W e are talking about the third political force, whose ideological orientations will be clearly formed and will replace the government in the future, but the contours of such force is now here to be seen.

W e could call the Presidential election of 2018 an elections without "a leader" because the Presidential candidates were not able to show leadership skills and the success of the "National M ovement" and "Georgian Dream" candidates was behind the activeness of the forces backing them and we could share a perturbing phrase: the choice was made between "the bad and worse" but President Salome Zurabishvili in his inaugural speech announces new democratic values in Georgian politics, which gives positive expectations to society.

The President that her biggest challenge is to overcome aggressive, violent political orientations and establish modern, democratic culture: "unity of the country, the consolidation of the society and the strengthening of our place in Europe - this is my main goal. I will convince fellow citizens that national consent for development and unification of Georgia is essentially important." ${ }^{133}$

For the first time in the history of Georgia the woman became the President and the transfer of the position was peaceful and civilized, "thus another democratic step", which can not be disagreeable.

Salome Zurabishvili emphasized the necessity of protecting the political heritage and for the first time in the Georgia's latest history evaluated the activities of the predecessor President positively;

It should be noted that every President has put his bricks on the road to the building of independent and democratic Georgia;

A century ago, the leaders of the first Republic adopted a modern and progressive constitution at that time;

Zviad Gamsakhurdia played the greatest role when he appointed a referendum and adopted the act of restoring Georgia's independence.

Eduard Shevardnadze was the first to pave the way to the European and Euro-A tlantic space;

\footnotetext{
${ }^{32} \mathrm{https}: / /$ www.osce.org/ka/ odihr/elections/georgia/404678? download=true\&fbclid=Iw AR3vDPFXRlibXIfYZZ8HSHuzhgLQ5XZ VyyCOwRTOYAsXWrl1k8c_KhV9bE (Seen on December 15 of 2018)

${ }^{33} \mathrm{https}: / /$ www.osce.org/ka/odihr/elections/georgia/404678?download=true\&fbclid=Iw AR3vDPFXRlibXIfYZZ8HSHuzhgLIQ5XZ VyyCOwRTOYAsXWrl1k8c_KhV9bE (Seen on December 15 of 2018)
} 
Mikheil Saakashvili laid the basis for many important reforms at the initial stage of his administration;

During the Presidency of Giorgi M argvelashvili steps were taken towards strengthening the democratic processes and stability.

My purpose is to do everything to ensure the development of our State, its European future, irreversible and so nothing could hinder our main goal. ${ }^{34}$

During the transition period, the greatest harm to the unity of the society was dealt by the national movement government, who denied Ilia's admonision about the objective regularity of inheritance ("son should know where his father has stoped") and removed older generation from social activities, shifted the focus on differentiative options of generations and social groups and practically divided the public consciousness. Salome Zurabishvili is well aware of the threat of solidarity and support and indicates:

"Solidarity is essential for stren gthening our society - first of all, solidarity between generations, which historically characterized us. It should not be lost." 35

In Georgian political thinking, the ruling and opposition elites have strengthened the excessive hopes of western partners and international organizations, the key to the independence of the country was completely withdraw $n^{36}$ and activated the consciousness of false expectations, which is part of the Georgian mentality ("Imitate the stranger"). "Georgia's political strategy lies in the fact that, says Professor M. Bichuashvili, the Georgian national State should be built on the basis of global international organizations: NATO will create the Georgian army, the International M onetary Fund will strengthen the economy, the OSCE will resolve the issue of territorial integrity, the Hague will elliminate all of the injustice". ${ }^{37}$

Zurabishvili made her emphasis on culture and rich traditions and emphasized: "Georgians can be usefull to the world with its old, wealthy, original culture that stands on Christianity. Georgian civilization can boldly establish its place in the world.

Our identity is historically revealed in tolerance. The tradition of peaceful coexistence with people of different origin and beliefs has been with us for centuries. Georgia is also famous for the fact that there is no example of anti-Semitism here. Tolerance is something that todays world lacks. W e must

\footnotetext{
${ }^{34}$ https:// www.osce.org/ka/odihr/elections/georgia/404678? download=true\&fbclid=lwAR3vDPFXRlibXIfYZ18HSHuzhgLL5XZ VyyCOwRTOYAsXWrl1k8c_KhV9bE (Seen on December 15 of 2018)

${ }^{35} \mathrm{https}$ :/ www.osce.org/ka/odihr/ elections/georgia/404678? download=true\&fbclid=lwAR3vDPFXRlibXIfYZ18HSHuzhgLIQ5XZ VyyCOwRTOYAsXWrl1k8c_KhV9bE (Seen on December 15 of 2018)

${ }^{36}$ Tabeshadze, T. James Appathurai says that the final assessment of Georgia's Presidential election was positive. Tbilisi: First Channel

37 Vakhtang Natsvlishvili, "Presidential Election: Anger and Hopelessness in Georgia" 2018. https:// ge.boell.org/ka/2018/.../saprezidento-archevnebi-brazi-da-uimedoba-sakartvelo. (Seen on January 18 of 2018)
} 
strengthen this tradition so that we become an example for others. W e should increase the awareness of Georgian culture and identity on the international arena". ${ }^{38}$

Zurabishvili focused on the necessity of development of the regions of Georgia. The President knows well that unequal development of the regions has often led to separatism and the country's dismemberment: "the path of development goesthrough the strong and prosperous regions. I think it is notew orthy that the inauguration of the President is held not in the capital of the country but in one of the regions of Kakheti, and it is my choice".

The modern, European-type State implies equal development of regions and capital. The foundation of Georgia was historically al ways its regions and their strength. W e can combine this historical experience and a modern European example ... I am sure that every Georgian's dream is returning of as many emigrants as possible to their villages and abandoned houses." 39

W hen speaking about foreign policy orientation, Zurabishvili's position is firm and consistent: "Russia, as a neighbor of the Caucasus, should realize that if he wants to be a full member of the international community and to restore normal relations in the region, it should prove recognizes all international law verbally and factually. This is necessary to establish equal and peaceful ties with its neighbors.

I believe that Georgia will be united. We should remember that people living in the occupied territories are our citizens and we should condone them. Past unites us with Abkhazians and Ossetians, we are relatives of each other, we have mixed families! W e need to find ways to get to the new generation and pave them a way to Europe. Today, as never before, A bkhaz language and identity needs protection! "40

Let's conclude the conclusion by quoting David Ost, that democracy is born where angry people, driven with power and weal th, become solidarity to each other and demand something that already bel ongs to them. ${ }^{41}$

So far, the government and opposition only produce hatred on the Georgian political scene, and there is no force visible that will be able to chanell this hatred in favor of democracy.

\footnotetext{
${ }^{38} \mathrm{https}$ :/ www.osce.org/ka/ odihr/ elections/georgia/404678? download=true\&fbclid=Iw AR3vDPFXRlibXIfYZZ8HSHuzhgLIQ5XZ VyyCOwRTOYAsXWrl1k8c_KhV9bE (Seen on December 15 of 2018)

${ }^{39} \mathrm{https}$ :// www. osce.org/ka/odihr/ elections/georgia/404678? download=true\&fbclid=lw AR3vDPFXRlibXIfYZZ8HSHuzhgLLQ5XZ VyyCOwRTOYAsXWrl1k8c_KhV9bE (Seen on December 15 of 2018)

${ }^{40} \mathrm{https}$ :/ www.osce.org/ka/odihr/ elections/georgia/404678? download=true\&fbclid=Iw AR3vDPFXRlibXIfYZZ8HSHuzhgLIQ5XZ VyyCOwRTOYAsXWrl1k8c_KhV9bE (Seen on December 15 of 2018)

${ }^{41} 35$. https://www.President.gov.ge/ka-GE/prezidenti/inauguracia.aspx. Salome Zurabishvili's inaugural speech (Seen on December 27 of 2018)
} 


\section{Used literature:}

1. Constitution of Georgia. Tb; 1995

2. Constitution of Georgia. Tb; 2004

3. Constitution of Georgia. Tb; 2018 P. 25

4. Constitution of Georgia. Tb; 2018 P. 42

5. Constitution of Georgia. Tb; 2018 P. 29

6. https://www.google.com/search?q=GEL impairment dynamics since 2014

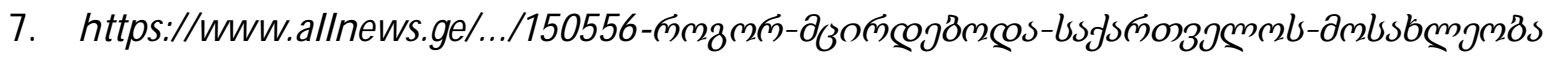

8. A.Tukvadze. Transformation of the political system in modern Georgia, in the journal: Central A sia and the Caucasus 2006 2(44) Sweden, Sweden 103-112.

9. A .Tukvadze. Comparative analysis of political culture. Tb; 2014 P. 125.

10. A.Tukvadze, U. Bluashvili. Peculiarities of Georgian character. See International reviewed and referential Scientific Journal. "Science and Life". Tb; 2011 №1(3) P. 101-102.

11. netgazeti.ge/news/314260/ N etgazeti | Unfulfilled promises of candidates (seen on 27.11.2018)

12. S.F.Johns. Democracy in Georgia https://.www.cicerofoundation.org.legtures.Stephen/onesGeorgia.pdf (seen on M arch 3 of 2017)

13. The results of the first round of the elections were summarized | imedinew shttps://imedinews.ge >

14. The exit poll results assessed by the ruling team/ imedin ews https://imedinews.ge >

15. Salome Zurabishvili appointed as the Foreign Minister of Georgia on Saturday. www.radiotavisupleba.ge. (Read on Novemebr 30 of 2018.)

16. Salome Zurabishvili's path to the Presidency. www.ghn.ge. Read on: December 4 of 2018.

17. Salome Zurabishvili opened the first office of her public movement. civil.ge. Read on:December 4 of 2018

18. Salome Zurabishvili's political timeout www.radiotavisupleba.ge. (read on: December 2 of 2018).

19. Salome Zurabishvili about the Presidential elections. www.radiotavisupleba.ge. (Read on: December 11 of 2018).

20. Parliamentary elections 2016 - second round. cec.gov.ge. (read on: November 30 of 2018.)

21. Georgian Dream will support Salome Zurabishvili during the Presidential elections. on.ge. (Read on: November 18 of 2018.)

22. Salome Zurabishvili refused the French citizenship. netgazeti.ge. Read on: November 16 of 2018.

23. Grigol Vashadze's biography, online edition "civil.ge".

24. M inistry of Foreign Affairs of Georgia - Biography; Read on: 3/18/2011

25. Nino Kharadze. Salome Zurabishvili vs Grigol Vashadze. Tb; Radio "Freedom" 2018

26. M inister of Foreign Affairs Grigol Vashadze again in concession of Russian citizenship, 2011

27. https://www.youtube.com/watch?v=elXpF_jTbb0 (Seen on December 18 of 2018) 
28. http://portal.coe.ge/downloads/Resolutions/Res1633(2009)Geo.pdf) (Seen on December 15 of 2018)

29. https://droa.ge/?p=38356 (Seen on N ovember 30 of 2018)

30. International Election Observation M ission Georgia - "Presidential Elections, Second Tour" 28 November 2018.

31. https://www.osce.org/ka/odihr/elections/georgia/404678?download=true\&fbclid=lwAR3vDPF XRlibXIfYZ18HSHuzhgLIQ5XZVyyCOWRTOYAsXW rl1k8c_KhV9bE (Seen on December 15 of 2018)

32. National Democratic Institute (NDI), elections of 2018, https://www.ndi.org/sites/default/files/N DI\%20Georgia_runoff\%20election\%20Press\%20relea se_GEO.pdf (Seen on December 15 of 2018)

33. Tabeshadze, T. James A ppathurai says that the final assessment of Georgia's Presidential election was positive. Tbilisi: First Channel

34. Vakhtang Natsvlishvili, "Presidential Election: Anger and Hopelessness in Georgia" 2018. https://ge.boell.org/ka/2018/.../saprezidento-archevnebi-brazi-da-uimedoba-sakartvelo. (Seen on January 18 of 2018)

35. https://www.President.gov.ge/ka-GE/prezidenti/inauguracia.aspx. Salome Zurabishvili's inaugural speech (Seen on December 27 of 2018)

36. Туквадзе А.А, Убилава И.Д..Лидер в грузинской политике.Вестник Российского университета дружбы народов. Серия: Политология.Volume 19,№1(2017). P. 72.

37. M. Bichashili. Lectures in political force theory. Tb; 2006 P. 113.

38. David Ost, "Solidarity and the politics of anti-politics", pg. 67, 1991. 